\title{
Model Discovery Learning Berbantu Google Meet Untuk Meningkatkan Hasil Belajar Kognitif Siswa Pada Materi Sistem Ekskresi
}

\author{
Hana Habibah Ma'mun*, Muhammad Muttaqin, Ukit, Tri Wahyu Agustina \\ UIN Sunan Gunung Djati Bandung, Indonesia \\ *Coresponding Author: hanahabibah11@gmail.com
}

Article History:

Received 2021-09-15

Revised 2022-01-04

Accepted 2022-01-22

DOI:

10.31949/educatio.v8i1.1508

\begin{abstract}
Learning is a way to improve cognitive learning outcomes. Field observations show that the cognitive learning outcomes of the excretory system material are below the KKM value because the learning process is dominated by teachers not students. This study aims to describe the activities of teachers and students with the discovery learning model with the help of google meet, analyze the cognitive learning outcomes of the discovery learning model with the help of google meet, analyze the effect of the discovery learning model with the help of google meet and describe the students' responses to the discovery learning model with the help of google meet on the excretory system material. The research method uses a quasiexperimental research design with Nonequivalent Control Group Design. The results of the research on teacher and student activities with discovery learning assisted by google meet obtained a very good category, student learning outcomes with discovery learning assisted by google meet obtained a post-test score that was better than the pre-test score. Student responses to the discovery learning model assisted by google meet have a strong category. The conclusion of this study is that the discovery learning model assisted by Google Meet on the excretory system material has an effect on students' cognitive learning outcomes.
\end{abstract}

Keywords: discovery learning; google meet; excretory system.

\section{PENDAHULUAN}

Kasus Covid-19 muncul pada tanggal 19 Desember 2019 muncul serupa dengan pneumonia yang tidak diketahui di Wuhan, China (Lee, 2020). Kasus tersebut di akibatkan oleh virus corona atau yang dikenal dengan COVID-19 (Corona Virus Desese-2019). Wabah COVID-19 mendesak pengujian pendidikan jarak jauh yang belum pernah dilakukan secara serempak sebelumnya (Sun, et al., 2020) bagi semua elemen pendidikan yakni peserta didik, guru hingga orang tua. Mengingat pada masa pandemic, waktu, lokasi dan jarak menjadi 
permasalahan besar saat ini (Kusuma \& Hamidah, 2020). Oleh karena itu pembelajaran jarak jauh menjadi solusi untuk mengatasi kesulitan dalam melaksanakan pembelajaran secara tatap muka. Hal ini memberikan tantangan kepada semua elemen dan jenjang pendidikan untuk mempertahankan kelas tetap aktif meskipun sekolah ditutup (Herliandry et al., 2020).

Proses pembelajaran terjadi melalui banyak cara atau media baik disengaja ataupun tidak disengaja yang berlangsung sepanjang waktu menuju perubahan pada peserta didik (Trianto, 2012). Model pembelajaran yang tepat dimanfaatkan sebagai acuan perencanaan dalam pembelajaran yang baik dan sesuai dengan bahan ajar yang disampaikan oleh guru (Arifin, 2017). Model pembelajaran yang baik menjadikan siswa lebih aktif dan tidak pasif, bersemangat, menikmati pembelajaran, tidak monoton, dan memiliki pengalaman yang sesungguhnya.

Salah satu model pembelajaran yang sesuai pada masa darurat adalah model discovery learning. Discovery learning adalah model pembelajaran yang mengacu pada konstruktivisme, yang lebih memfokuskan kepada pemahaman susunan dalam mata pelajaran melalui partisipasi aktif siswa agar mampu membuat suatu kumpulan tanya jawab yang aktif ketika pembelajaran berlangsung dan mampu menemukan sesuatu di lingkungannya. Pembelajaran ini diantaranya paham terhadap materi, makna dan interaksi secara intuitif, kemudian menarik sebuah gagasan singkat (Budiningsih, 2005).

Berdasarkan hasil angket yang telah disebar melalui google form kepada siswa kelas XII MAN 2 Sumedang dengan jumlah 20 siswa yang sudah mempelajari materi sistem ekskresi di kelas XI ditemukan beberapa masalah diantaranya 1) sulit memahami materi pada kondisi pandemi 2) terdapat kendala dalam pembelajaran sistem ekskresi pada masa pandemi karena tidak ada praktikum di sekolah serta kendala media pembelajaran dan jaringan yang kurang memadai 3) pemahaman dan ketertarikan siswa terhadap materi sistem ekskresi masih rendah 4) nilai hasil ujian harian dibawah nilai 65 pada materi sistem ekskresi.

Menindaklanjuti permasalahan tersebut, dilakukan penelitian kepada siswa kelas XI MIPA 1 dan 2 di MAN 2 Sumedang dengan tujuan untuk mengetahui pengaruh model pembelajaran disecovery learning berbantu google meet pada materi sistem ekskresi. Penelitian ini difokuskan untuk meningkatkan hasil belajar kognitif siswa, indikator hasil kognitif yaitu knowledge (mengetahui/ mengingat), comprehension (memahami), application (menerapkan), analysis (menganalisis), synthesis (memadukan) dan evaluation (mengevaluasi) serta berperan dalam meningkatkan proses pembelajaran siswa agar lebih baik.

\section{METODE PENELITIAN}

Metode yang digunakan pada penelitian yaitu metode eksperimen yang digunakan untuk mencari pengaruh perlakuan terhadap variabel terikat dalam kondisi terpantau. Ciri khas metode eksperimen adalah adanya kelompok kontrol, sebagai bagian dari metode kuantitatif (Sugiyono, 2014).

Desain yang digunakan adalah desain Quasi eksperimen karena pada penelitian ini terdapat variabel pembanding atau variabel kontrol. Metode ini dipilih dengan tujuan untuk mengetahui pengaruh variabel bebas terhadap variabel terikat (Sugiyono, 2014). Metode yang digunakan adalah Pretest-Posttest Nonequivalent Control Group Design dengan menggunakan dua kelas yaitu kelas eksperimen (dengan menggunakan model Discovery learning berbantu google-meet) dan kelas kontrol (tanpa menggunakan model Discovery learning berbantu google-meet).

Penelitian ini dilakukan di MAN 2 Sumedang dengan populasi siswa kelas XI semester genap tahun ajaran 2021/2022 yang terdiri dari dua kelas diantaranya XI MIPA-1 dan XI MIPA-2. Sampel dipilih menggunakan purposive sampling yaitu startegi untuk menentukan sampel dengan pertimbangan tertentu agar tercapainya penelitian ini. Sampel yang digunakan tidak dipilih secara acak. Penelitian ini menggunakan dua kelas sebagai sampel yaitu kelas XI MIPA-1 sebagai kelas eksperimen yang menggunakan model iscovery learning berbantu google meet dan kelas XI MIPA-2 sebagai kelas kontrol yang tidak menggunakan model discovery learning berbantu google meet.

Teknik yang digunakan dalam pengumpulan data di lapangan yaitu lembar observasi, tes, dan angket. Lembar observasi untuk mengetahui keadaan nyata di tempat penelitian, tes untuk mengukur hasil belajar siswa pada materi sistem ekskresi berupa 24 soal pilihan ganda, dan kuisioner terbuka untuk mengetahui 
respon siswa terhadap model discovery learning berbantu google meet. Data yang terkumpul diolah dan dianalisis secara kualitatif dan kuantitatif.

\section{HASIL DAN PEMBAHASAN}

1. Keterlaksanaan Model Pembelajaran Discovery Learning Berbantu Google Meet

Keterlaksanaan pembelajaran dengan menggunakan model discovery learning berbantu google meet dapat diketahui dari hasil pengamatan dengan menggunakan lembar observasi aktivitas guru dan aktivitas siswa.

Keterlaksanaan aktivitas guru dengan Model Discovery Learning berbantu Google Meet dapat dilihat pada tabel 1.

Tabel 1. Keterlaksanaan Aktivitas Guru Model Discovery Learning Berbantu Google Meet

\begin{tabular}{ccccc}
\hline Tahap & \multicolumn{4}{c}{ Aktivitas Guru } \\
Pembelajaran & Pertemuan 1 & Pertemuan 2 & Presentase & Kriteria \\
\hline Pendahuluan & 6 & 6 & $100 \%$ & Sangat baik \\
Kegiatan inti & 14 & 14 & $100 \%$ & Sangat baik \\
Penutup & 2 & 2 & $100 \%$ & Sangat baik \\
\hline
\end{tabular}

Berdasarkan tabel 1 semua aktivitas guru menggunakan model discovery learning berbantu google meet memperoleh nilai presentasi $100 \%$ dengan kriteria sangat baik.

Pembelajaran kelas eksperimen dengan menggunakan model discovery learning berbantu google meet dimulai dengan guru mengucapkan salam, menyapa siswa, berdoa dan mengabsen siswa. Kemudian guru menyampaikan tujuan pembelajaran serta motivasi belajar kepada siswa. Hal ini selaras dengan Permendikbud Nomor 65 (2013) menyatakan bahwa dalam kegiatan pendahuluan, guru diharuskan memberikan motivasi belajar kepada siswa secara konseptual. Selaras dengan pendapat Mubarok \& Sulistyo (2016) yang menyatakan bahwa dalam pembelajaran, faktor pemberian motivasi mempunyai pengaruh yang penting dikarenakan motivasi merupakan pencurahkan segala tenaga untuk mencapai tujuan pembelajaran yang diinginkan.

Kegiatan inti yang dilaksanakan guru pada kelas eskperimen dengan menggunakan model discovery learning berbantu google meet yaitu (1) pemberian stimulation (rangsangan pembelajaran) berupa video, kemudian guru mengajukan pertanyaan "Apa yang kalian pahami mengenai video tersebut?" (2) problem statement (identifikasi masalah), guru memerintah siswa untuk membuat problem statement (3) data collection, guru memerintah siswa mengumpulkan data/informasi mengenai sistem ekskresi secara berkelompok (4) data processing (pengolahan data), guru memerintah siswa mengolah data yang telah diperoleh dengan menelaah (5) verification (pembuktian), guru memerintah siswa untuk melakukan verifikasi data dengan kelompok belajar yang lain (6) generalization (menyimpulkan), guru memerintah siswa untuk merumuskan dan menyimpulkan materi hasil verifikasi yang telah dilakukan.

Keberhasilan pengajaran bergantung pada kemampuan mengatur kelas yang dapat menciptakan situasi nyaman dalam kegiatan belajar. Hal ini sama dengan kutipan Fahrurrazi (2018) yang menyatakan bahwa strategi pengelolaan kelas yang efektif adalah pola dan siasat dengan langkah-langkah pembelajaran yang digunakan guru dalam menciptakan kondisi kelas yang kondusif. Selaras dengan pendapat Prayitno yang mengatakan bahwa untuk menciptakan suasana yang dapat menumbuhkan gairah belajar, meningkatkan prestasi belajar siswa, maka diperlukan pengorganisasian kelas yang memadai (Prayitno, 2009).

Pembelajaran pada kelas eksperimen dengan menggunakan model discovery learning berbantu google meet yaitu guru memberi kesempatan kepada siswa untuk menyimpulkan pembelajaran dan melakukan evaluasi terhadap materi sistem ekskresi. Hal ini sejalan dengan Kartowagiran (2011) guru sebagai salah satu bagian dari pendidik profesional memiliki tugas utama membimbing, menilai, dan mengevaluasi siswa. Sejalan dengan pendapat Rimawati \& Haryanto (2017) yang mengatakan bahwa kompetensi guru merupakan kemampuan, keahlian dan keterampilan yang harus dimiliki oleh guru dalam menjalankan proses pembelajaran sampai kepada pengevaluasian.

Berbeda dengan aktivitas guru, hasil pengamatan pada aktivitas menunjukkan ada aktivitas siswa pada kegiatan inti pembelajaran tidak dilaksanakan. Keterlaksanaan aktivitas siswa dengan Model Discovery 
Learning berbantu Google Meet dapat dilihat pada tabel 2. Berdasarkan Tabel 2.9 aktivitas siswa menggunakan model discovery learning berbantu google meet memperoleh rata-rata nilai presentasi 100\% dengan kriteria sangat baik. Adapun aktivitas siswa yang tidak terlaksana pada kelas eksperimen pertemuan pertama yaitu siswa tidak membuat problem statement/identifikasi masalah mengenai materi sistem ekskresi. Hal demikian dapat terjadi karena siswa tidak fokus terhadap perintah guru. Hal ini berpengaruh kepada hasil belajar siswa pada indikator menganilisis keterkaitan antara struktur dan fungsi organ ginjal yang menghasilkan kategori rendah.

Tabel 2. Keterlaksanaan Aktivitas Siswa Model Discovery Learning Berbantu Google Meet

\begin{tabular}{ccccc}
\hline Tahap & & \multicolumn{3}{c}{ Aktivitas Siswa } \\
Pembelajaran & Pertemuan 1 & Pertemuan 2 & Persentase & Kriteria \\
\hline Pendahuluan & 5 & 5 & $100 \%$ & Sangat baik \\
Kegiatan inti & 11 & 13 & $61 \%$ & Baik \\
Penutup & 2 & 2 & $100 \%$ & Sangat baik \\
\hline
\end{tabular}

Berdasarkan hasil analisis aktivitas siswa dalam setiap pertemuan diperoleh kesimpulan bahwa pembelajaran menggunakan model discovery learning berbantu google meet terlaksana dengan sangat baik. Keterlaksanaan proses pembelajaran ini merupakan hal utama yang diharapkan dalam melaksanakan proses pembelajaran, salah satunya dengan menggunakan model pembelajaran yang tepat. Menurut Joyce dalam Trianto (2012) mengungkapkan bahwa model pembelajaran merupakan suatu rangkaian rencana yang digunakan sebagai pedoman dalam merencanakan pembelajaran dan berfungsi menentukan perangkat pembelajaran.

2. Peningkatan Hasil Belajar Kognitif Siswa Pada Materi Sistem Ekskresi Dengan Model Discovery Learning Berbantu Google Meet

Untuk melihat hasil yang diperoleh dari pembelajaran dengan Model Discovery Learning Berbantu Google Meet maka dilakukan tes. Hasil tes belajar kognitif siswa dapat dilihat pada Tabel 3.

Tabel 3. Rata-rata N-Gain Hasil Belajar Kognitif Siswa

\begin{tabular}{ccccc}
\hline Kelas & Pretest & Postetst & N-Gain & Interpretasi \\
\hline Ekesperimen & 54,17 & 61,46 & 0,12 & Tinggi \\
Kontrol & 40,63 & 58,75 & 0,03 & Rendah \\
\hline
\end{tabular}

Berdasarkan Tabel 3 diperoleh nilai rata-rata pretest yaitu 54,17 dan posttest 61,46 serta N-Gain 0,12 dengan interpretasi tinggi. Berdasarkan jumlah keseluruhan dari dua puluh siswa pada kelas eksperimen, tiga belas siswa memperoleh nilai di atas KKM dan tujuh siswa memperoleh nilai di bawah KKM. Nilai KKM yang ditetapkan pihak sekolah pada materi sistem ekskresi yaitu 65.

Berdasarkan analisis tersebut, terlihat bahwa C1, C2, C3 dan C5 merupakan ranah proses kognitif yang mendapatkan rata-rata N-Gain dengan kategori tinggi. Sesuai dengan karakteristik jenis soal C1 sampai C3 menurut bloom merupakan kemampuan kognitif yang paling rendah dan paling dasar, sehingga jenis soal C1 merupakan jenis soal yang termasuk dalam jenis soal menghapal. Adapun pada indikator soal C4 memperoleh rata-rata $N$-Gain dengan kategori rendah. Selaras dengan Bloom yang mengatakan bahwa proses menganalisis termasuk tingkatan kognitif paling tinggi dikarenakan siswa belum dibiasakan dalam melakukan analisis soal saat mengerjakan tugas-tugas yang diberikan guru di sekolah. Wilson (2020) menyatakan bahwa sedikitnya pertanyaan guru yang menuntut pemikiran tingkat tinggi kepada siswa menunjukkan pembelajaran belum melatih siswa untuk mengembangkan pemikiran tingkat tinggi dan mengakibatkan skor yang rendah.

Hasil belajar pada kelas eksperimen memperoleh nilai $N$-Gain 0,12 dengan kategori tinggi yang berarti penggunaan model pembelajaran discovery learning berbantu google meet dalam meningkatkan hasil belajar kognitif siswa pada materi sistem ekskresi tergolong tinggi. Ranah kognitif berkenaan dengan hasil belajar intelektual yang terdiri dari empat aspek, yakni pengetahuan atau ingatan, pemahaman, aplikasi, analisis, sintesis dan evaluasi (Sudjana, 2009). Hasil belajar merupakan sesuatu yang dinilai ketika siswa sudah melaksanakan proses 
pembelajaran dari semua aspek, yaitu kognitif, afektif dan psikomotor (Arikunto, 2009). Hal ini sejalan dengan Iskandar (2016: 67) yang menyatakan keunggulan model pembelajaran discovery learning yaitu menjadikan siswa memanfaatkan berbagai sumber belajar untuk mengembangkan keterampilan siswa, membantu siswa meningkatkan konsep karena siswa berkelompok untuk mendapatkan kepercayaan diri sehingga hasil belajar dapat meningkat. Sejalan dengan penelitian Sulistianingrum et al. (2014) membuktikan bahwa pembelajaran discovery learning berpengaruh terhadap aktivitas dan hasil belajar siswa.

3. Pengaruh Model Pembelajaran Discovery Learning Berbantu Google Meet Terhadap Hasil Belajar Kognitif Siswa Pada Materi Sistem Ekskresi

Pengaruh pembelajaran discovery learning berbantu google meet terhadap hasil belajar kognitif siswa pada materi sistem ekskresi dapat dilihat pada tabel 4.

Tabel 4. Hasil Analisis Posttest

\begin{tabular}{|c|c|c|c|}
\hline \multicolumn{2}{|c|}{ Analisis Data Posttest } & Kelas Eksperimen & Kelas Kontrol \\
\hline \multirow[t]{3}{*}{ Normalitas } & $\mathrm{X}_{\text {hitung }}$ & 0,190 & 0,129 \\
\hline & $\mathrm{X}_{\text {tabel }}$ & 0,294 & 0,294 \\
\hline & Keterangan & Normal & Normal \\
\hline \multirow[t]{3}{*}{ Homogenitas } & F & \multicolumn{2}{|c|}{1,12} \\
\hline & $\mathrm{F}_{\text {tabel }}$ & \multicolumn{2}{|c|}{2,17} \\
\hline & Keterangan & \multicolumn{2}{|c|}{ Homogen } \\
\hline \multirow[t]{3}{*}{ Uji Hipotesis (Uji t) } & thitung & \multicolumn{2}{|c|}{2,50} \\
\hline & tabel & \multicolumn{2}{|c|}{2,02} \\
\hline & Keterangan & \multicolumn{2}{|c|}{$\mathrm{H}_{0}$ ditolak, $\mathrm{H}_{1}$ diterima } \\
\hline
\end{tabular}

Berdasarkan Tabel 4 hasil belajar pada kelas eksperimen memperoleh nilai N-Gain 0,12 dengan kategori tinggi. Hal ini menunjukkan bahwa penggunaan model pembelajaran discovery learning berbantu google meet dapat meningkatkan hasil belajar kognitif siswa pada materi sistem ekskresi. Diperoleh hasil analisis uji normalitas pada kelas eksperimen dengan Xhitung 0,190 dan Xtabel 0,294 dengan keterangan normal. Adapun hasil analisis uji normalitas pada kelas kontrol diperoleh nilai dengan Xhitung 0,129 dan Xtabel 0,294 dengan keterangan normal. Hasil analisis uji homogenitas kelas eksperimen diperoleh nilai dengan Fhitung 1,12 dan Ftabel 2,17 dengan keterangan homogen. Hasil analisis uji hipotesis (Uji t) diperoleh nilai dengan thitung 2,50 dan ttabel 2,02 dengan keterangan $\mathrm{H} 0$ ditolak dan H1 diterima yang berarti terdapat pengaruh model pembelajaran discovery learning berbantu google meet terhadap hasil belajar kognitif siswa pada materi sistem ekskresi.

Hanafiah \& Suhana (2012) menjelaskan bahwa discovery learning merupakan kegiatan pembelajaran yang melibatkan secara maksimal seluruh kemampuan siswa untuk menyelidiki secara sistematis, kritis, dan logis sehingga siswa dapat menemukan sendiri pengetahuan, sikap, dan keterampilan sebagai wujud adanya perubahan perilaku. Pembelajaran discovery learning mengarahkan siswa untuk memahami konsep, arti, dan hubungan, melalui proses intuitif untuk akhirnya sampai kepada suatu kesimpulan (Kemendikbud, 2013). Sejalan dengan pendapat Borthick dan Jones (2000: 51) menyatakan bahwa pembelajaran discovery learning bertujuan untuk lebih mengenali masalah, mencari solusi, mencari informasi yang relevan, mengembangkan strategi solusi, dan melaksanakan strategi yang dipilih.

Pengaruh pembelajaran menggunakan model discovery learning berbantu google meet dalam proses belajar mengajar tersebut tentunya tidak terlepas dari peran guru dalam pencapaian hasil belajar siswa. Hal tersebut tidak terlepas dari peran guru sebagai fasilitator, monitor dan evaluator selama proses belajar mengajar berlangsung. Hal ini relevan dengan pendapat Suwardi (2003) yang menyatakan bahwa peran guru dalam proses pembelajaran sebagai infomator/komunikator, organisator, konduktor, motivator, fasilitator, evaluator dan pendidik.

Berdasarkan analisis keseluruhan, model pembelajaran discovery learning berbantu google meet dapat mempengaruhi hasil belajar kognitif siswa pada materi sistem ekskresi. Hal tersebut dapat terlihat dari siswa yang diberikan model pembelajaran discovery learning berbantu google meet memperoleh nilai rata-rata hasil belajar 
siswa lebih besar dibandingkan dengan kelas yang tanpa menggunakan model pembelajaran discovery learning berbantu google meet.

4. Respon Siswa Terhadap Penggunaan Model Discovery Learning Berbantu Google Meet

Respon siswa terhadap pembelajaran dengan model discovery learning berbantu google meet pada materi sistem ekskresi diperoleh dari hasil angket respon siswa. Respon yang telah dianalisis melalui perhitungan angket pada Tabel 5 .

Tabel 5. Rekapitulasi Respon Siswa terhadap Model Discovery Learning berbantu Google Meet

\begin{tabular}{llcc}
\hline No & \multicolumn{1}{c}{ Aspek } & $\begin{array}{l}\text { Rata - rata } \\
\text { presentase }\end{array}$ & Keterangan \\
\hline 1 & $\begin{array}{l}\text { Respon siswa terhadap model pembelajaran } \\
\text { discovery learning berbantu google meet }\end{array}$ & $71,25 \%$ & Kuat \\
2 & $\begin{array}{l}\text { Respon siswa terhadap aktivitas pembelajaran } \\
\text { dengan metode discovery learning berbantu google meet }\end{array}$ & $73,75 \%$ & Kuat \\
Respon siswa mengenai pengaruh metode \\
pembelajaran discovery learning berbantu google \\
meet pada sistem ekskresi \\
Rata - rata keseluruhan
\end{tabular}

Berdasarkan Tabel 5 respon positif siswa terhadap model pembelajaran dengan metode discovery learning berbantu google meet memiliki nilai rata-rata persentase $71,25 \%$. Respon terhadap model pembelajaran discovery learning berbantu google meet masih dalam kategori kuat, tidak mampu mencapai kategori sangat kuat. Hal ini dikarenakan terdapat hambatan dan kekurangan. Menurut Sugiyono (2013) kelemahan model discovery learning yaitu siswa membutuhkan IQ tinggi, jika tidak hasilnya cenderung kurang berkreativitas dan membutuhkan waktu lama dalam memahami suatu konsep yang dipelajari. Sejalan dengan Darmuki (2002) mengungkapkan bahwa kelemahan model discovery learning yaitu siswa harus memiliki kesiapan dan kematangan mental, harus berani dan berkeinginan untuk mengetahui keadaan sekitarnya dengan baik.

Respon siswa terhadap aktivitas pembelajaran dengan metode discovery learning berbantu google meet memiliki rata-rata persentase kuat yaitu sebesar $73,75 \%$. Hal tersebut karena pembelajaran dilaksanakan seacara berkelompok sehingga siswa menemukan ide-ide baru. Respon siswa pada pengaruh metode pembelajaran discovery learning berbantu google meet terhadap pelaksanaan pembelajaran sistem ekskresi juga memiliki persentase kuat $(74,25 \%)$. Hal ini dikarenakan siswa dapat menggali informasi dengan mudah.

Berdasarkan hasil analisis respon siswa terhadap model discovery learning berbantu google meet dengan nilai rata-rata presentase secara keseluruhan yaitu $73,08 \%$. Hal tersebut dapat menunjukkan bahwa respon siswa terhadap model discovery learning berbantu google meet kuat.

\section{KESIMPULAN}

Berdasarkan analisis data hasil penelitian mengenai pengaruh pembelajaran model discovery learning berbantu google meet terhadap hasil belajar kognitif siswa pada materi sistem ekskresi, maka dapat diambil kesimpulan aktivitas guru selama pembelajaran menunjukan kategori sangat baik, begitu juga dengan aktivitas menunjukkan kategori sangat baik. Hasil belajar kognitif siswa yang menggunakan pembelajaran discovery learning berbantu google meet pada materi sistem ekskresi memperoleh nilai rata-rata lebih baik dibanding kelas kontrol dengan skor N-Gain dalam kategori tinggi. Hasil tersebut menjadikan Model pembelajaran discovery learning berbantu google meet berpengaruh terhadap hasil belajar siswa pada materi sistem ekskresi.

\section{DAFTAR PUSTAKA}

Arikunto, S. (2009). Penelitian Tindakan Kelas. Jakarta: Bumi Aksara.

Arifin, Z. (2017). Kriteria Instrumen dalam Suatu Penelitian. Jurnal Theorems, 2(1). 4 - 24.

Budiningsih, A. (2005). Belajar dan Pembelajaran. Jakarta: Rineka Cipta.

Cartono. 2005. Biologi Umum untuk Perguruan Tinggi. Bandung: Prism Press. 
Darmuki, A. (2020). Upaya meningkatkan kemampuan berbicara mahasiswa menggunakan media aplikasi Google Meet berbasis unggah tugas video di youtube pada masa pandemi Covid-19. Jurnal Educatio FKIP UNMA, 6(2), 655-661.

Fahrurrazi. (2018). Mudah dan Aktif Belajar Biologi untuk Kelas XI SMA/MA Program IPA. Jakarta: PT Setia Purna Invas.

Hanafiah \& Suhna. (2012). Kurikulum dan Pembelajaran. Jakarta: Bumi Aksara.

Herliandry, L. D., Nurhasanah, N., Suban, M. E., \& Kuswanto, H. (2020). Pembelajaran pada masa pandemi covid-19. JTP-Jurnal Teknologi Pendidikan, 22(1), 65-70.

Iskandar, A. (2020). Aplikasi Pembelajaran TIK. Sumatera Utara : Kita Menulis.

Jones. (2015). Pengaruh Model Discovery learning Terhadap Hasil Belajar Siswa Pada Materi Pokok Suhu dan Kalor. Jurnal Ikatan Alumni Fisika Universitas Negeri Medan. Vol 1. No 1. Hal 30.

Kartowagiran. (2011). Creating Virtual Classroom (Using Google Hangouts) For Improving Language Competency. Language Issues: The ESOL Journal 26 (1): 37- 42

Klahr, D., \& Nigam, M. (2004). The equivalence of learning paths in early science instruction: Effects of direct instruction and discovery learning. Psychological science, 15(10), 661-667.

Kusuma, J. W. Platform Whatsapp Group Dan Webinar Zoom Dalam Pembelajaran Jarak Jauh Pada Masa Pandemik Covid 19 Universitas Bina Bangsa. Serang email:[email protected] Universitas Bina Bangsa, Serang email:[email protected] Abstrak. Pendabuluan Ditengah wa, 5.

Mubarok, C., \& Sulistyo, E. (2014). Penerapan model pembelajaran discovery learning terhadap hasil belajar siswa kelas $\mathrm{x}$ tav pada standar kompetensi melakukan instalasi sound system di smk negeri 2 surabaya. Jumal Pendidikan Teknik. Elektro, 3(2).

Prayitno. (2009). Proses Belajar Mengajar di Sekolah. Jakarta: PT Rineka Cipta

Rimawati, R., \& Haryanto, S. (2017). Penerapan pendekatan saintifik dengan model pembelajaran kooperatif tipe talking stik motivasi dan prestasi belajar. Wiyata Dharma: Jurnal Penelitian dan Evaluasi Pendidikan, 5(2), 103-114.

Sudjana, N. (2009). Penilaian Hasil Proses Belajar Mengajar. Bandung: PT. Remaja Rosda Karya.

Sugiyono. (2010). Cooperative Learning Teori dan Aplikasi PAIKEM. Yogyakarta: Pustaka Belajar

Sulistianingrum, F. D., Sutrisno, S., \& Su'aidy, M. (2017). Pengaruh Pembelajaran Inkuiri Terbimbing Terhadap Pemahaman Larutan Penyangga Dan Keterampilan Proses Sains Peserta Didik. J-PEK Jurnal Pembelajaran Kimia), 2(1), 31-40.

Suwardi 2003. Teori Belajar dan Pembelajaran. Bandung: Remaja Rosdakarya.

Trianto. (2012). Model- Model Pembelajaran Inovatif. Jakarta : Prestasi Pustaka.

Wilson, A. (2020). Penerapan Metode Pembelajaran Daring (Online) Melalui Aplikasi Berbasis Android Saat Pandemi Global. SAP (Susunan Artikel Pendidikan), 5(1). 